\title{
NAMA MAKANAN OLAHAN BUAH PISANG: STUDI ETNOSEMANTIS
}

\author{
THE NAME OF BANANA PROCESSED FOOD: AN ETHNOSEMANTIC STUDY
}

\section{Dian Mahendra; Fatimah Azzahra; Eka Nur Ummu Khasanah}

\author{
Fakultas Ilmu Budaya, Universitas Gadjah Mada \\ Bulaksumur, Caturtunggal, Kecamatan Depok, Kabupaten Sleman, \\ Daerah Istimewa Yogyakarta, Indonesia \\ henndra94@gmail.com; fatimah9949@gmail.com; khasanah.ekaummu@gmail.com
}
(Naskah diterima tangga 17 Juni 2021, direvisi terakhir tanggal 25 Oktober 2021, dan disetujui tanggal 22 November 2021)

DOI: https:/ / doi.org/10.26499/wdprw.v49i2.853

\begin{abstract}
The study aims to identify the cultural aspects inside the names of banana processed foods through an ethnosemantic approach. The discussed research includes the forms of linguistic units used as the names, the basis for naming, the modernization of traditional food names, and the classification of folk foods. Presented data were obtained through the observation method and the literature studies. The data were analyzed in a qualitative and quantitative methodology. Qualitatively, the data were analyzed by distributional method with immediate constituent technique. The quantitative analysis method was used to figure out the percentage of the use of the essential food naming in the names of bananas processed foods, the number of the traditional name food development becoming modern food, and the number of food name filling in the categories of the folk food system classification. The results showed two forms of food names, namely words and phrases. The basis for naming food is divided into eleven categories, such as the naming based on the basic ingredients, the types of essential elements, the shapes, the processing methods, the additional ingredients, the characters, the brand, the size, the taste, the manufacturer's name, and the place name. The terms of these foods have been modernization, and some are not. The names of the traditional foods such as "nagasari", "pisang rebus", and "tape pisang" have not undergone modernization. Meanwhile, traditional foods are undergoing modernization, such as "pisang goreng" has been developing into 24 variants, "pisang bakar" into three variants, "bongko pisang" into three variants, "kolak pisang" into three variants, "sale pisang" into four variants, "ledre pisang" into five variants, "rambak pisang" into three variants, and "keripik pisang" into six variants. In addition, the name of banana processed food is also found in a new modified form. Regarding the classification of folk food, the names of the banana processed foods are classified into five categories: the unique beginner (the type of the food), the food form (the form of the food), the generic, the specific, and the specific the varietal.
\end{abstract}

Keywords: food names; banana processed food; folk nomenclature system; folk classification; ethnosemantics

Abstrak
Studi ini bertujuan untuk mengidentifikasi aspek budaya di balik nama-nama makanan olahan buah
pisang melalui pendekatan etnosemantis. Masalah yang dibahas meliputi bentuk-bentuk satuan
kebahasaan yang digunakan sebagai nama, dasar penamaan, modernisasi nama makanan tradisional,
dan klasifikasi folk makanan. Data yang disajikan diperoleh melalui metode observasi dan studi pustaka.
Data tersebut kemudian dianalisis secara kualitatif dan kuantitatif. Secara kualitatif, data dianalisis
dengan metode agih teknik bagi unsur langsung. Adapun analisis kuantitatif digunakan untuk
mengetahui persentase penggunaan dasar penamaan makanan dalam nama-nama makanan olahan


pisang, jumlah perkembangan nama makanan tradisional yang menjadi makanan modern, dan jumlah nama makanan yang mengisi kategori-kategori dalam sistem klasifikasi folk makanan tersebut. Hasil analisis menunjukkan dua bentuk nama makanan olahan pisang, yakni kata dan frasa. Dasar penamaannya dibedakan menjadi sebelas, yakni penamaan berdasarkan bahan pokok, jenis bahan pokok, bentuk, cara pengolahan, bahan tambahan, sifat, merek, ukuran, rasa, nama pembuat, dan nama tempat. Nama-nama makanan tersebut ada yang mengalami modernisasi dan ada yang tidak. Nama makanan tradisional nagasari, pisang rebus, dan tape pisang tidak mengalami modernisasi. Sementara itu, makanan tradisional pisang goreng berkembang menjadi 24 varian, pisang bakar menjadi tiga varian, bongko pisang menjadi tiga varian, kolak pisang menjadi tiga varian, sale pisang menjadi empat varian, ledre pisang menjadi lima varian, rambak pisang menjadi tiga varian, dan keripik pisang menjadi enam varian. Selain itu, nama makanan olahan pisang juga ditemukan dalam bentuk modifikasi baru. Mengenai klasifikasi folk makanan, nama makanan olahan pisang dikelompokkan menjadi lima kategori, yaitu unique beginner (jenis makanan), food form (bentuk makanan), generik, spesifik, dan varietal.

Kata-kata Kunci: nama makanan; olahan buah pisang; sistem tata nama rakyat; klasifikasi folk makanan; etnosemantis

\section{Pendahuluan}

Salah satu fungsi bahasa adalah untuk mengidentifikasi, menamai, dan mengklasifikasikan hal-hal yang ada di sekitar manusia. Identifikasi, penamaan, dan klasifikasi tersebut dilakukan oleh masyarakat setempat dengan menggunakan pengetahuan mereka sendiri (pengetahuan tradisional). Dengan pengetahuan tersebut, masyarakat setempat menamai tumbuhan, hewan, dan mikroorganisme (Kalle dan Sõukand, 2021: 1-16; Nugraha, 2019: 186-95; Phaka dkk., 2019: 1-8; Suhandano, 2007: 89-97; Wang dkk., 2020: 127). Selain itu, masyarakat setempat juga menamai dan mengklasifikasikan bendabenda mati yang ada di sekitarnya.

Terkait hal di atas, Loko dkk. (2018: 1-15) dan Tokuoka dkk. (2019: 1-10) menyatakan bahwa taksonomi dan tata nama rakyat merupakan hal yang umum di dunia. Pengetahuan tradisional tentang klasifikasi, identifikasi dan tata nama tersebut telah menunjukkan nilai yang signifikan dalam konservasi alam dan pemanfaatan keanekaragaman hayati (lih. Turpin dan Si, 2017: 12040; Ulicsni, Svanberg, dan Molnár, 2016: 140). Pengetahuan tradisional yang terkait dengan keanekaragaman hayati meliputi sis- tem tata nama rakyat, pemanfaatan sumber daya hayati yang tersedia, dan pengelolaan ekosistem oleh masyarakat lokal di suatu wilayah (Huai dan Pei, 2000: 528-36).

Sistem tata nama rakyat diterapkan oleh masyarakat Indonesia salah satunya untuk menamai nama-nama makanan yang diolah dari buah pisang. Nama-nama makanan tersebut menarik untuk dikaji, setidaknya dilihat dari tiga hal. Pertama, buah pisang merupakan salah satu hasil pertanian yang sangat melimpah di Indonesia. Sebagai buah yang kaya akan vitamin, masyarakat Indonesia mengonsumsi buah pisang dengan mengolahnya menjadi berbagai macam olahan makanan. Selain itu, buah pisang dikenal sebagai buah yang penuh manfaat, bahkan limbah buah pisang pun masih dapat dimanfaatkan untuk membuat aneka olahan makanan (Amiruddin, Rozek, dan Sulistiyanto, 2019: 12-18; Gurning, Puarada, dan Fuadi, 2021: 106-11).

Kedua, nama-nama makanan olahan buah pisang berkembang dari masa ke masa. Pada awalnya, makanan olahan buah pisang hanya dinamai dengan nama-nama tradisional. Akan tetapi, seiring dengan perkembangan ilmu dan teknologi serta berkem- 
bangnya kreativitas manusia, nama-nama tersebut berkembang menjadi nama-nama makanan modern dengan berbagai variasi. Munculnya variasi makanan olahan pisang tersebut berhubungan dengan upaya meningkatkan nilai jual pisang sehingga dapat menunjang perekonomian masyarakat (Qurniati dkk., 2020: 117-24; Sadapotto dan Hasan, 2020: 88-100; Sunandar dkk., 2017: 815). Ketiga, nama-nama makanan olahan buah pisang berkaitan dengan budaya masyarakat yang menciptakan nama tersebut. Nama-nama makanan tersebut juga dapat mencerminkan perkembangan budaya masyarakat penuturnya.

Berdasarkan paparan-paparan di atas, aspek budaya yang terkandung dalam sistem tata nama rakyat dalam penamaan makanan olahan buah pisang perlu dikaji. Kajian dapat dilakukan melalui studi etnosemantik. Dengan studi semacam itu, nama-nama makanan olahan buah pisang pertama-tama akan ditinjau dari aspek formal bahasa. Aspek itu meliputi bentuk-bentuk satuan kebahasaan yang digunakan dalam sistem tata nama tersebut dan relasi makna antar satuan kebahasaan yang menjadi unsur pembentuk nama tersebut. Setelah itu, dengan mempertimbangkan satuan-satuan kebahasaan yang digunakan sebagai unsur pembentuk nama, nama-nama makanan tersebut dipilah menjadi makanan tradisional dan modern. Terakhir, dengan mempertimbangkan aspek formal bahasa, nama-nama makanan tersebut diklasifikasikan berdasarkan klasifikasi rakyat (folk).

Penelitian yang berhubungan dengan tata nama rakyat telah banyak dilakukan. Dalam ranah makanan, studi yang cukup lengkap dilakukan oleh Hadiyaniyah (2016: 94-102) yang mengkaji mengenai leksikon makanan tradisional Sunda. Studi tersebut mengklasifikasikan nama makanan berdasarkan bentuk, dasar penamaan, dan bahan pokok pembuatan makanan. Dalam hal dasar penamaan, studi tersebut kurang memperhatikan unsur-unsur satuan kebahasaan yang membentuk nama makanan. Artinya, ia mengidentifikasi dasar penamaan makanan hanya berdasarkan pada satu satuan lingual yang membentuk nama tersebut; satuan kebahasaan lainnya tidak diperhitungkan. Padahal, munculnya suatu satuan lingual dalam sebuah nama, pasti memiliki dasar. Dengan demikian, sebuah nama makanan bisa jadi memiliki lebih dari satu dasar penamaan.

Terkait dasar penamaan makanan, beberapa ahli bahasa lainnya (seperti Fransiska, Reniwati, dan Lindawati, 2019: 2331; Mulyadi, 2019: 50-63; Munjidah, 2019: 182-89; dan Nuari, 2020: 73-90) juga menunjukkan hasil analisis yang sama dengan Hadiyaniyah (2016: 94-102). Mereka juga mengidentifikasi dasar penamaan makanan berdasarkan salah satu unsur satuan kebahasaan yang membentuk nama makanan tanpa mempertimbangkan satuan kebahasaan lainnya. Selain itu, studi yang mereka lakukan belum ada yang sampai pada pembahasan mengenai klasifikasi folk makanan di samping belum berupaya untuk mengidentifikasi modernisasi makanan tradisional. Oleh karena itu, penelitian ini berupaya memperluas temuan-temuan sebelumnya dengan cara mengidentifikasi aspek-aspek yang belum diteliti.

Untuk mengidentifikasi masalah-masalah yang dikaji dalam studi ini, diperlukan konsep dan teori yang tepat dan relevan. Teori yang digunakan ialah teori etnosemantis. Eglin (1980: 19) menyebutkan bahwa studi etnosemantis merupakan studi yang berkaitan dengan kumpulan istilah yang memiliki ciri makna yang sama. Misalnya, istilah kekerabatan, istilah warna, istilah tumbuhan, dan istilah hewan. Lebih lanjut, ia menegaskan bahwa etnosemantik berkaitan dengan seperangkat aturan semantik. Aturan seperti itu menyatakan kondisi di 
mana istilah tertentu dapat menamai objek tertentu.

Baehaqie (2017: 21) menyatakan bahwa etnosemantis merupakan istilah yang bersinonim dengan etnolinguistik. Studi semacam ini berkaitan dengan cara-cara yang dipakai oleh suatu masyarakat dalam mengidentifikasikan, mengorganisasikan, dan mengklasifikasikan ranah-ranah pengetahuan tertentu. Pengidentifikasian, pengorganisa-sian, dan pengklasifikasian tersebut terkait erat dengan budaya penuturnya.

Berdasarkan paparan di atas, studi ini membicarakan empat masalah terkait nama makanan olahan pisang. Masalah-masalah tersebut ialah (1) klasifikasi bentuk nama makanan olahan buah pisang berdasarkan satuan lingual pembentuknya, (2) dasar penamaan makanan olahan buah pisang, (3) modernisasi nama makanan olahan buah pisang, dan (4) klasifikasi folk makanan olahan buah pisang.

\section{Metode}

Studi etnosemantis dengan pendekatan mixtype (kualitatif-kuantitatif) digunakan untuk mengidentifikasi dimensi budaya di balik beragamnya nama makanan olahan buah pisang di Indonesia. Data yang disajikan diperoleh melalui metode observasi dan studi pustaka. Observasi dilakukan dengan cara mengamati lingkungan sekitar kemudian mengidentifikasi nama-nama makanan olahan buah pisang yang ditemukan. Observasi dipusatkan di Kabupaten Gresik (Jawa Timur), Kabupaten Kulon Progo (DIY), Kabupaten Sleman (DIY), dan Kabupaten Lombok Barat (NTB). Adapun studi pustaka dilakukan dengan cara menelusuri namanama makanan di internet dan aplikasiaplikasi e-commerce, seperti Go-Food, GrabFood, Tokopedia, dan Shopee.

Setelah data terkumpul, data-data tersebut kemudian dianalisis secara kualitatif dan kuantitatif. Analisis kualitatif digunakan untuk mengidentifikasi bentuk-bentuk satuan kebahasaan nama makanan, dasar penamaan makanan, klasifikasi folk makanan olahan buah pisang, dan dimensi budaya yang tersirat di balik nama-nama tersebut. Identifikasi bentuk dilakukan dengan metode agih teknik bagi unsur langsung (lih. Kesuma, 2007: 55; Muhammad, 2011: 239; Sudaryanto, 2015: 37-38). Dengan teknik ini, dapat diketahui satuan kebahasaan apa yang membentuk nama makanan tersebut. Untuk mengidentifikasi dasar penamaan makanan, dilakukan analisis relasi makna antarsatuan kebahasaan yang membentuk nama makanan tersebut. Sementara itu, klasifikasi folk makanan olahan buah pisang dilakukan dengan mengadopsi klasifikasi folk biologi.

Secara kuantitatif, analisis data dilakukan untuk mengetahui persentase penggunaan dasar penamaan makanan dalam namanama makanan olahan buah pisang, mengetahui jumlah perkembangan nama makanan tradisional yang menjadi makanan modern, dan mengetahui jumlah nama makanan yang mengisi kategori-kategori dalam sistem klasifikasi folk makanan tersebut. Analisis secara kuantitatif dalam hal ini digunakan untuk memfasilitasi analisis kualitatif (lih. Dörnyei, 2007: 160-70). Datadata kuantitatif yang diperoleh digunakan untuk menunjang deskripsi kualitatif.

Hasil analisis data disajikan dengan dua cara, yakni informal dan formal (lih. Mahsun, 2014: 123). Secara informal, hasil analisis data disajikan dengan menggunakan deskripsi kata ke kata secara detail dan jelas. Pada pelaporan secara formal, hasil analisis disajikan dengan menggunakan simbol, lambang, tabel, dan bagan.

\section{Hasil dan Pembahasan}

Uraian berikut akan memaparkan hasil penelitian yang berupa klasifikasi bentuk nama makanan olahan pisang berdasarkan terminologi yang sama dan standar, klasifikasi 
dasar penamaannya, klasifikasi folk penamaannya, dan dimensi budaya yang tecermin di balik penamaan tersebut.

\subsection{Klasifikasi Bentuk Nama Makanan}

Nama-nama makanan olahan buah pisang secara linguistik dibentuk dengan memadukan leksem-leksem. Ada dua bentuk satuan kebahasaan yang berhasil diidentifikasi dalam penamaan makanan tersebut, yakni nama makanan berbentuk kata dan frasa. Kedua bentuk satuan kebahasaan tersebut akan diuraikan pada bagian berikut.

\subsubsection{Kata}

Nama makanan olahan pisang yang berbentuk kata dibedakan menjadi dua, yakni nama makanan berbentuk idiom dan akronim. Nama makanan berbentuk idiom hanya ditemukan satu nama. Nama makanan itu ialah nagasari. Nagasari merupakan salah satu makanan olahan buah pisang yang terbuat dari campuran tepung beras, santan, gula, dan pisang yang dibungkus dengan daun pisang dan dikukus. Nama nagasari dibentuk dari penggabungan dua kata dasar, yakni kata naga dan sari. Secara leksikal, naga berarti ular yang besar dan sari berarti isi utama atau pokok isi dari suatu benda.

Satuan lingual nagasari dikatakan sebagai idiom karena entitas leksikal tersebut lebih berfungsi sebagai kata, walaupun terdiri dari gabungan kata (lih. Katamba 1993: 291). Selain itu, makna gramatikal dari idiom tersebut tidak bisa dirunut dari makna unsurunsur pembentuknya. Dengan perkataan lain, makna kata naga dan kata sari sama sekali tidak berhubungan dengan makna yang ditimbulkan akibat bergabungnya dua kata tersebut yang menjadi kata nagasari.

Selain berbentuk idiom, nama makanan olahan buah pisang juga ditemukan dalam bentuk akronim. Sejauh ini, batasan akronim memang masih banyak diperdebatkan. Zaim (2015: 173-192) mendefinisikan akronim secara spesifik sebagai singkatan yang berupa gabungan huruf awal dari deret kata yang ada. Misalnya, LHK (linguistik historis komparatif), HAKI (hak kekayaan intelektual), WIL (wanita idaman lain), dan sebagainya. Di sisi lain, banyak ahli bahasa (seperti Chaer, 2015: 236-37; Kridalaksana, 2009: 5; dan Muslich, 2014: 36) mendefinisikan akronim sebagai singkatan yang berupa gabungan huruf atau suku kata atau bagian lain yang ditulis dan dilafalkan sebagai kata karena kesesuaiannya dengan kaidah fonotaktik bahasa yang bersangkutan. Definisi kedua ini memang lebih luas dari definisi sebelumnya. Namun, batasannya menjadi sangat jelas, yakni diperlakukan sebagaimana layaknya sebuah kata yang wajar.

Dari seluruh nama makanan olahan yang diidentifikasi, ada satu nama makanan yang berupa akronim. Nama makanan tersebut adalah banroll. Banroll merupakan akronim dari banana roll dalam bahasa Inggris yang bermakna 'pisang gulung' dalam bahasa Indonesia. Akronim ini dibentuk dengan menggabungkan suku kata pertama kata banana, yakni [ban] dan suku kata pertama dari roll, yakni [roll] sehingga membentuk banroll. Akronim ini juga diperlakukan sebagaimana layaknya kata yang wajar karena dapat digunakan sebagai unsur pembentuk satuan kebahasaan lainnya. Pertimbangkan nama makanan (1)-(3) berikut.

(1) banroll sang pisang chocholate

(2) banroll sang pisang green tea

(3) banroll sang pisang avocado

Nama-nama makanan di atas menunjukkan bahwa akronim banroll diperlakukan seperti kata yang wajar. Akronim tersebut berkategori nomina dan digunakan sebagai inti dari suatu konstruksi frasa nominal. Unsur-unsur kebahasaan selain akronim 
banroll dalam frasa nama makanan (1)--(3) berfungsi sebagai modifikator bagi unsur inti banroll. Pembahasan lebih lanjut mengenai hal ini dibicarakan pada bagian frasa.

\subsubsection{Frasa}

Selain nagasari dan banroll, semua nama makanan olahan buah pisang berbentuk gabungan kata yang berupa frasa. Secara bentuk, frasa didefinisikan sebagai satuan gramatikal yang terdiri dari dua kata atau lebih, tetapi tidak melebihi batas fungsi (Ba'dulu dan Herman, 2005: 58). Jenis-jenis frasa dapat dipilah berdasarkan perilaku sintaksis unsur-unsurnya dan berdasarkan kategori intinya.

Berdasarkan perilaku sintaksis unsurunsurnya, frasa yang digunakan sebagai nama makanan olahan buah pisang termasuk ke dalam frasa endosentris atributif. Frasa semacam ini merupakan frasa yang salah satu unsurnya memiliki perilaku sintaksis yang sama dengan keseluruhannya (lih. Chaer, 2014: 226). Frasa ini juga disebut sebagai frasa subordinatif karena unsurunsur pembentuknya memiliki kedudukan yang tidak setara. Satu unsur menjadi unsur inti sebagai komponen atasan dan satu atau lebih modifikator sebagai komponen bawahan (Busri dan Badrih, 2018: 95). Secara semantis, Chaer (2014: 227) menyatakan bahwa frasa ini juga sering disebut sebagai frasa modifikatif karena modifikator (unsur selain inti) dari frasa ini dapat mengubah atau membatasi makna unsur intinya. Pertimbangkan frasa nama makanan (4) - (8) berikut.
(4) pisang goreng
(5) pisang bakar
(6) pisang bakar kacang
(7) keripik pisang
(8) keripik pisang asin

Nama makanan (4)--(8) masing-masing memiliki satu inti frasa. Frasa (4)--(6) menggunakan kata pisang sebagai inti, sedangkan frasa (7) dan (8) menggunakan kata keripik sebagai inti. Salah satu unsur yang membentuk kelima frasa nama makanan di atas memiliki perilaku sintaksis yang sama dengan keseluruhannya. Pertimbangkan satuan kebahasaan (9) dan (10) berikut.

(9) a. Pisang goreng itu enak.

b. Pisang - itu enak.

(10) a. Zahra memakan pisang bakar kacang.

b. Zahra memakan pisang - -.

Kalimat (9a) dan (10a) di atas menunjukkan penggunaan frasa nama makanan (4) dan (6) dalam kalimat. Dalam kalimat (9b) dapat diketahui bahwa frasa nama makanan (4) memiliki perilaku sintaksis yang sama dengan salah satu unsur pembentuknya, yakni kata pisang. Begitu juga dengan frasa nama makanan (6) yang digunakan dalam kalimat (10b) menunjukkan bahwa frasa tersebut memiliki perilaku sintaksis yang sama dengan salah satu unsur pembentuknya, yaitu kata pisang. Perilaku sintaksis seperti ini juga berlaku bagi frasa nama makanan (5), (7), dan (8).

Berdasarkan kedudukan unsur-unsur pembentuknya, frasa nama makanan (4)--(8) masing-masing terdiri dari satu inti dan satu atau lebih modifikator. Inti frasa tersebut memiliki kedudukan yang lebih tinggi dibandingkan modifikator. Frasa (4), (5), dan (7), masing-masing, terdiri dari atas inti dan satu modifikator. Frasa (5) dan (6) masingmasing menggunakan kata pisang sebagai inti dan kata goreng dan bakar sebagai modifikator. Sementara itu, frasa (7) menggunakan kata keripik sebagai inti dan kata pisang sebagai modifikator. Di sisi lain, frasa nama makanan (6) dan (8) terdiri dari satu inti dan dua modifikator. Frasa (6) menggunakan 
kata pisang sebagai inti frasa dan kata bakar dan kacang sebagai modifikator, sedangkan frasa (8) menggunakan kata keripik sebagai inti dan kata pisang dan asin sebagai modifikator.

Hubungan antara inti frasa dan modifikator seperti yang dikemukakan di atas dapat mempengaruhi makna inti frasa. Kata pisang, yang merupakan inti dari frasa nama makanan (4), akan berubah maknanya menjadi 'pisang yang digoreng' ketika kata tersebut diikuti oleh modifikator goreng. Hal ini juga berlaku untuk inti frasa (5)--(8). Frasa (5) bermakna 'pisang yang dibakar', frasa (6) bermakna 'pisang yang dibakar dan ditaburi kacang di atasnya', frasa (7) bermakna 'keripik yang dibuat dari pisang', dan frasa (8) bermakna 'keripik yang dibuat dari pisang dan memiliki rasa asin'. Hubungan makna semacam ini akan dibahas lebih lanjut pada bagian dasar penamaan makanan olahan buah pisang. Alasannya karena dasar penamaan makanan dapat diketahui melalui hubungan makna antarunsur kebahasaan yang membentuk nama makanan tersebut.

Selanjutnya, berdasarkan kategori kata yang menjadi inti, semua nama makanan olahan buah pisang (selain nagasari) berbentuk frasa nominal. Frasa nominal merupakan frasa yang intinya berupa nomina (Moeliono dkk., 2017: 310). Ramlan (2005: 145) mendefinisikan frasa semacam ini sebagai frasa yang distribusinya sama dengan nomina. Frasa nominal dapat dibentuk dengan cara memperluas satuan berkategori nomina, baik ke kiri atau ke kanan (lih. Muslich, 2014: 94). Dalam hal ini, satuan kebahasaan yang membentuk nama makanan olahan buah pisang merupakan frasa nominal yang diperluas dari inti nomina ke arah kanan. Pertimbangkan kembali frasa nama makanan (4)--(8) di atas.

Frasa nama makanan (4)--(8) memiliki inti berkategori nomina. Inti berupa nomina tersebut diperluas dengan modifikator ke arah kanan. Adapun kategori modifikator yang digunakan untuk memperluas inti nomina dalam frasa nama makanan olahan buah pisang adalah nomina, verba, adjektiva, dan frasa nominal. Pertimbangkan frasa nama makanan (11)--(15) berikut.

(11) pisang cokelat $[\mathrm{N}]_{\text {inti }}+[\mathrm{N}]_{\text {mod. }}$

(12) pisang rebus $[\mathrm{N}]_{\text {inti }}+[\mathrm{V}]_{\text {mod. }}$

(13) molen pisang mini $[\mathrm{N}]_{\text {inti }}+[\mathrm{N}+\text { Adj. }]_{\text {mod. }}$

(14) pisang geprek cokelat kacang $[\mathrm{N}]_{\text {inti }}+[\mathrm{V}+\mathrm{N}+\mathrm{N}]_{\text {mod. }}$

(15) banroll sang pisang chocholate $[\mathrm{N}]_{\text {inti }}+\left[\mathrm{FN}\left([\mathrm{p}]_{\text {mod. }}+[\mathrm{N}]_{\text {inti }}\right)+\mathrm{N}\right]_{\text {mod. }}$

Frasa nama-nama makanan di atas ada yang memiliki satu modifikator, dua modifikator, tiga modifikator, dan empat modifikator. Frasa (11) memiliki satu modifykator berkategori nomina, yakni cokelat. Frasa (12) memiliki satu modifikator berkategori verba, yakni rebus. Frasa (13) menggunakan dua modifikator, yakni nomina pisang, dan adjektiva mini. Sementara itu, modifikator dalam frasa (14) ada tiga, yakni kata geprek $(\mathrm{V})$, cokelat $(\mathrm{N})$, dan kacang $(\mathrm{N})$. Frasa (15) menggunakan dua modifikator, yaitu frasa nominal sang pisang dan nomina chocholate. Frasa nomina sang pisang yang merupakan modifikator dalam frasa (15) terdiri dari inti berupa nomina pisang dan modifikator berupa partikel sang. Frasa ini merupakan frasa nominal yang diperluas ke kiri dengan partikel sang.

\subsection{Dasar Penamaan Makanan}

Sebagaimana telah dikemukakan sebelumnya, dasar penamaan makanan olahan buah pisang dapat diketahui melalui relasi makna antarsatuan lingual yang membentuk nama tersebut, terutama nama makanan yang berbentuk frasa. Adapun nama makanan yang berbentuk idiom tidak bisa diiden- 
tifikasi dasar penamaannya dari unsur-unsur yang membentuknya. Hal ini disebabkan karena konstruksi idiom menimbulkan makna baru yang sama sekali tidak berhubungan dengan unsur-unsur pembentuknya.

Identifikasi relasi makna antarsatuan kebahasaan yang membentuk nama makanan olahan buah pisang berhasil mengklasifikasikan dasar penamaan pisang menjadi sebelas. Dasar penamaan tersebut antara lain berdasarkan bahan pokok, jenis bahan pokok, bentuk, cara pengolahan, bahan tambahan, sifat, merek, ukuran, rasa, nama pembuat, dan nama tempat. Dasar penamaan untuk sebuah makanan tidak hanya terdiri atas satu dasar, tetapi dapat terdiri atas berbagai dasar penamaan. Pertimbangkan nama makanan (16)--(18) berikut.

(16) pisang geprek

(17) pisang bakar kacang

(18) keripik pisang manis

Nama-nama makanan di atas menunjukkan bahwa dasar penamaan makanan tersebut beraneka ragam. Nama makanan (16) didasarkan pada bahan pokok dan cara pengolahannya. Nama makanan (17) didasarkan pada bahan pokok, bentuk, dan cara pengolahannya. Sementara itu, nama makanan (18) didasarkan pada bentuk, bahan pokok, dan rasanya. Jika dilihat dari unsur satuan kebahasaan yang menjadi inti dari frasa nama makanan (16)--(18), dapat diketahui bahwa frasa nama makanan (16) dan (17) menggunakan dasar bahan pokok sebagai nama utama. Sementara itu, frasa nama makanan (18) menggunakan dasar bentuk seperti keripik sebagai dasar penamaannya. Dengan demikian, dapat dikatakan bahwa nama makanan (16) dan (17) lebih menonjolkan bahan utama, yakni pisang, sedangkan nama makanan (18) lebih menonjolkan bentuk makanannya sebagai nama utama. Istilah nama utama dalam hal ini adalah nama yang menempati posisi inti dalam konstruksi frasa nama makanan tersebut. sementara itu, satuan lingual yang berada di kanan nama utama disebut sebagai nama penjelas. Gambaran yang lebih jelas, dapat dilihat pada Tabel 1.

Tabel 1

Persentase Penggunaan Dasar Penamaan

\begin{tabular}{lc}
\hline \multicolumn{1}{c}{ Dasar Penamaan } & $\begin{array}{c}\text { Persentase } \\
\text { Penggunaan }\end{array}$ \\
\hline Nama Utama: & \\
1. Bahan pokok & $47 \%$ \\
2. Bentuk & $53 \%$ \\
Nama Penjelas: & \\
1. Jenis pisang & $1 \%$ \\
2. Cara pengolahan & $15 \%$ \\
3. Bahan tambahan & $64 \%$ \\
4. Sifat & $9 \%$ \\
5. Merek & $2 \%$ \\
6. Ukuran & $1 \%$ \\
7. Rasa & $2 \%$ \\
8. Nama pembuat & $1 \%$ \\
9. Nama tempat & $4 \%$ \\
\hline
\end{tabular}

Tabel 1 menunjukkan jumlah penggunaan dasar penamaan makanan dalam namanama makanan olahan buah pisang. Nama utama dalam sistem penamaan makanan tersebut didasarkan pada bahan pokok dengan persentase penggunaan sebanyak $47 \%$ dan bentuk dengan persentase penggunaan sebanyak $53 \%$. Persentase ini menunjukkan bahwa penutur bahasa Indonesia lebih banyak membuat nama makanan olahan buah pisang berdasarkan bentuknya. Bentuk-bentuk tersebut antara lain adalah kebab, bongko, roti, kolak, molen, ledre, sale, rambak, dan keripik.

Nama makanan yang didasarkan pada bentuk makanannya dianggap lebih menarik bagi konsumen dibandingkan dengan nama makanan yang dibentuk dari bahan pokoknya. Selain itu, nama makanan yang didasarkan pada bentuk ini juga dapat digunakan 
untuk menonjolkan aspek modernisasi dari makanan olahan buah pisang tersebut. Masalah modernisasi makanan olahan buah pisang akan dibahas pada bagian selanjutnya.

Data-data yang disajikan dalam Tabel 1 juga menunjukkan fakta menarik lainnya. Penamaan yang didasarkan pada jenis pisang memiliki persentase yang sangat rendah, yakni $1 \%$. Padahal, jenis-jenis pisang yang terdapat di Indonesia sangat beraneka ragam. Perhatikan nama makanan (19).

\section{(19) kolak pisang saba}

Nama makanan (19) merupakan satusatunya nama makanan olahan buah pisang yang penamaannya didasarkan pada jenis pisang yang digunakan. Dalam data tersebut terdapat frasa pisang saba yang merupakan salah satu jenis pisang yang ada di nusantara. Fakta ini cukup unik mengingat variasi pisang yang ada di nusantara sangat banyak, tetapi nama-nama tersebut tidak digunakan untuk menamai makanan. Nama-nama pisang di nusantara antara lain pisang susu, pisang lumut, pisang bulu, pisang muli, pisang nangka, dan sebagainya (lih. Putri dkk., 2015). Fakta ini menunjukkan bahwa jenis pisang yang digunakan dalam proses pengolahan makanan dianggap tidak penting bagi penutur bahasa Indonesia. Artinya, pisang apa pun yang digunakan tidaklah menjadi persoalan, yang penting adalah kreasi dan rasa dari olahan makanan tersebut.

Fakta menarik lainnya dari Tabel 1 adalah tingginya persentase penggunaan bahan tambahan sebagai dasar penamaan dalam nama-nama makanan olahan buah pisang. Adapun bahan tambahan tersebut dapat berupa cokelat, keju, madu, stroberi, kacang, selai, nanas, dan sebagainya. Fakta ini tidak terjadi begitu saja, tetapi berhubungan dengan budaya penutur bahasa
Indonesia. Penggunaan beraneka ragam bahan tambahan tersebut dalam nama-nama makanan olahan buah pisang dianggap dapat meningkatkan prestise makanan sehingga lebih menarik minat konsumen untuk membeli. Selain itu, penggunaan bahan tambahan tersebut juga dimaksudkan agar makanan olahan buah pisang yang dijual lebih bervariasi sehingga konsumen memiliki banyak pilihan sesuai dengan selera masingmasing.

\subsection{Modernisasi Nama Makanan Olahan Buah Pisang}

Seiring dengan perkembangan ilmu dan teknologi, nama-nama makanan olahan buah pisang tradisional juga mengalami perkembangan menjadi makanan modern. Modernisasi ini dapat diketahui melalui proses pembuatannya yang sudah menggunakan peralatan teknologi modern. Selain itu, unsur-unsur satuan kebahasaan yang membentuk nama makanan tersebut juga menandai modernitas suatu makanan. Nama-nama makanan tradisional yang mengalami modernisasi dapat dilihat pada Tabel 2.

Data-data yang disajikan dalam Tabel 2 menunjukkan bahwa nama makanan olahan buah pisang tradisional ada yang mengalami perkembangan menjadi makanan yang modern dan ada yang tetap mempertahankan ketradisionalannya. Delapan dari sebelas nama makanan tradisional tersebut mengalami transformasi menjadi nama makanan modern, sedangkan tiga nama lainnya tidak berubah. Nama makanan olahan buah pisang seperti nagasari, pisang rebus, dan tape pisang adalah nama-nama makanan yang tidak mengalami perkembangan pemodernan. Nama-nama makanan olahan buah pisang tradisional yang mengalami modernisasi ialah pisang goreng yang berkembang menjadi 24 varian, pisang bakar menjadi 3 varian, bongko pisang menjadi 3 varian, kolak pisang menjadi 3 varian, sale pisang menjadi 4 varian, 
ledre pisang menjadi 5 varian, rambak pisang menjadi 3 varian, dan keripik pisang menjadi 6 varian.

Tabel 2

Modernisasi Nama Makanan Olahan Buah Pisang

\begin{tabular}{clc}
\hline No. & \multicolumn{1}{c}{$\begin{array}{c}\text { Makanan } \\
\text { Tradisional }\end{array}$} & $\begin{array}{c}\text { Jumlah Makanan } \\
\text { Modern }\end{array}$ \\
\hline 1 & nagasari & 0 \\
2 & pisang goreng & 24 \\
3 & pisang bakar & 3 \\
4 & pisang rebus & 0 \\
5 & bongko pisang & 3 \\
6 & kolak pisang & 3 \\
7 & sale pisang & 4 \\
8 & tape pisang & 0 \\
9 & ledre pisang & 5 \\
10 & rambak pisang & 3 \\
11 & keripik pisang & 6 \\
\hline
\end{tabular}

Selain itu, modernisasi olahan buah pisang juga ditemukan dalam bentuk modifikasi. Pengembangan olahan buah pisang tersebut memiliki spesifikasi modifikasi dengan standar jenis makanan lain. Tabel 3 menyajikan nama-nama makanan yang mencakup fenomena itu.

Perkembangan nama makanan tradisional menjadi modern berhubungan dengan budaya penutur bahasa Indonesia. Dari nama-nama makanan tersebut dapat diketahui makanan seperti apa yang memiliki fungsi yang penting dalam kehidupan masyarakat. Dari sisi ekonomi, nama makanan seperti nagasari, pisang rebus, dan tape pisang dianggap kurang penting dalam kehidupan masyarakat Indonesia. Hal ini terbukti dengan tidak berkembangnya olahan makanan tersebut menjadi makanan yang modern. Bandingkan dengan nama makanan olahan buah pisang seperti pisang goreng, pisang bakar, bongko pisang, kolak pisang, keripik pisang, dan sebagainya. Nama-nama makanan tersebut dianggap memiliki fungsi yang lebih penting dalam kehidupan masyarakat Indonesia, terutama dari sisi ekonomi. Semakin banyak variasi nama makanan modern yang berkembang dari makanan tradisional, semakin penting fungsi makanan tersebut bagi suatu masyarakat.

\subsection{Klasifikasi Folk Nama Makanan Olahan Buah Pisang}

Klasifikasi folk nama makanan olahan buah pisang dalam studi ini mengadopsi klasifikasi folk biologi dengan beberapa penyesuaian. Dalam klasifikasi folk biologi, Suhandano (2000: 225-30, 2007: 89-97) menyatakan bahwa dalam semua bahasa ada kemungkinan untuk memisahkan kelompokkelompok makhluk hidup dari berbagai tingkat keinklusifan secara linguistik. Kelaskelas hasil pemisahan tersebut disebut sebagai taksa. Setiap taksa kemudian dapat dikelompokkan lagi ke dalam kelas-kelas

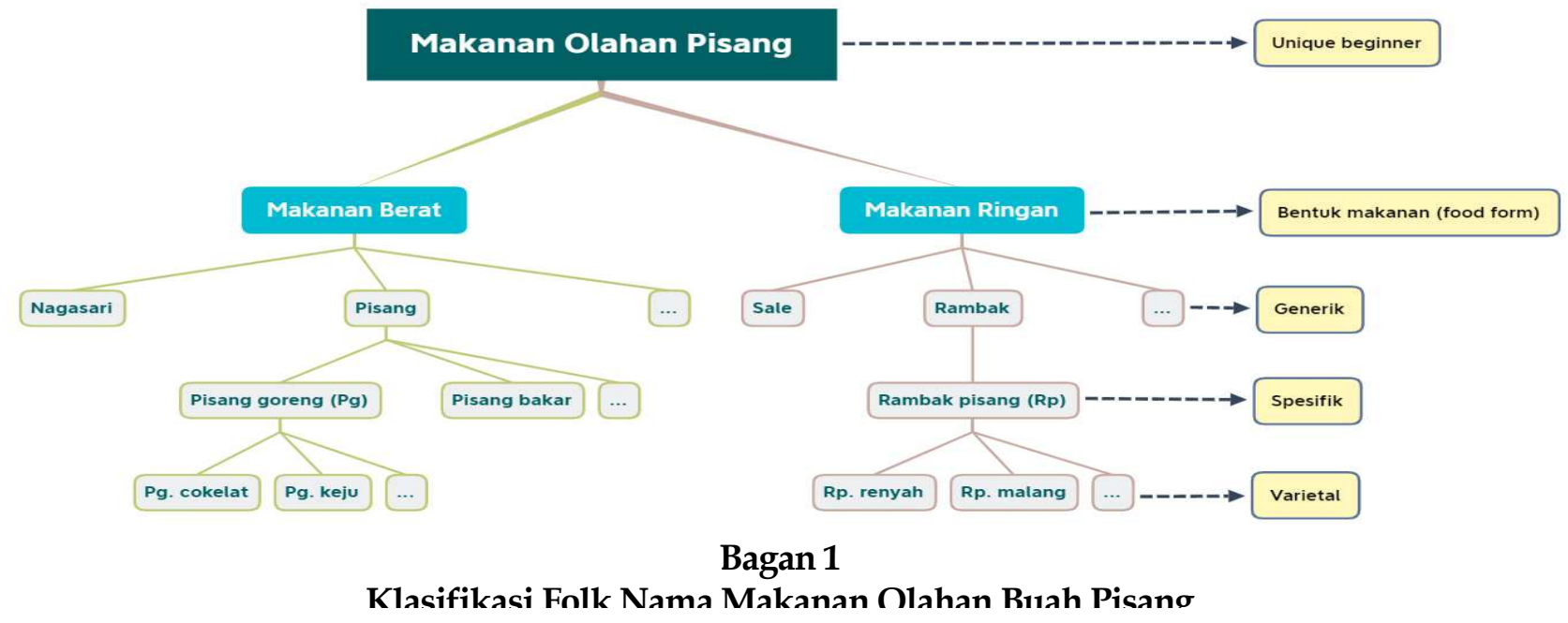


yang lebih kecil yang disebut sebagai kategori taksonomi etnobiologi. Lebih lanjut, Suhandano menegaskan bahwa kategori taksonomi biologi tersebut dapat ditentukan menggunakan kriteria linguistik dan taksonomi dan, biasanya, jumlahnya tidak lebih dari lima. Nama-nama kategori tersebut adalah unique beginner, life form, generic, specific, dan varietal.

Tabel 3

Modifikasi Baru Makanan Olahan Buah Pisang

\begin{tabular}{clc}
\hline No. & \multicolumn{1}{c}{$\begin{array}{c}\text { Makanan } \\
\text { Tradisional }\end{array}$} & $\begin{array}{c}\text { Jumlah } \\
\text { Variasi }\end{array}$ \\
\hline 1 & kebab pisang & 5 \\
2 & bongko pisang & 3 \\
3 & roti pisang & 6 \\
4 & molen pisang & 2 \\
5 & bolu pisang & 5 \\
6 & puding pisang & 3 \\
7 & pie pisang & 9 \\
8 & lumpia pisang & 6 \\
9 & dadar gulung pisang & 2 \\
10 & nuget pisang & 4 \\
\hline
\end{tabular}

Dengan mengadopsi klasifikasi folk biologi, nama makanan olahan buah pisang dapat dikelompokkan menjadi lima kategori. Kategori tersebut adalah unique beginner (jenis makanan), food form (bentuk makanan), generic (generik), specific (spesifik), dan varietal. Kategori jenis makanan berada pada posisi teratas dalam klasifikasi ini. Kategori tersebut diisi dengan satuan kebahasaan "makanan olahan buah pisang". Kategori jenis makanan ini membawahi dua kategori bentuk makanan, yakni makanan berat dan makanan ringan. Selanjutnya, kategori bentuk makanan tersebut juga membawahkan kategori generik, kategori generik membawahkan kategori spesifik, dan kategori spesifik membawahkan kategori varietal. Untuk lebih jelasnya, hierarki klasifikasi tersebut dapat dilihat pada Bagan 1.

Kategori makanan berat membawahkan delapan kategori generik. Kategori generik tersebut antara lain adalah nagasari, pisang, kebab, bongko, roti, kolak, molen dan ledre. Sementara itu, kategori bentuk makanan ringan membawahkan tujuh kategori generik, yaitu ledre, banana, bolen, sale, tape, rambak dan keripik. Tidak semua kategori generik membawahkan kategori spesifik dan tidak semua kategori spesifik membawahkan kategori varietal. Sebagai gambaran yang lebih jelas, perhatikan Tabel 4.

Dalam Tabel 4 dapat dilihat bahwa kategori generik nagasari tidak membawahkan kategori spesifik. Selain itu, dapat diketahui juga bahwa kategori spesifik pisang rebus dan tape pisang tidak membawahkan kategori varietal. Ketidakmunculan bentuk spesifik dari kategori generik nagasari dan ketidakmunculan bentuk varietal dari kategori spesifik pisang rebus dan tape pisang menunjukkan bahwa makanan-makanan tersebut memiliki fungsi yang kurang penting dalam kehidupan masyarakat nusantara. Semakin banyak kategori varietal di bawah kategori spesifik, semakin tinggi fungsi makanan yang berada pada kategori spesifik tersebut.

Tabel 4

Kategori Generik, Spesifik, dan Varietal dalam Klasifikasi FolkNama Makanan Olahan Buah Pisang

\begin{tabular}{cclc}
\hline $\begin{array}{c}\text { Bentuk } \\
\text { Makanan }\end{array}$ & $\begin{array}{c}\text { Kategori } \\
\text { Generik }\end{array}$ & \multicolumn{1}{c}{$\begin{array}{c}\text { Kategori } \\
\text { Spesifik }\end{array}$} & $\begin{array}{c}\text { Jumlah } \\
\text { Kategori } \\
\text { Varietal }\end{array}$ \\
\hline & nagasari & \multicolumn{1}{c}{0} & 0 \\
\cline { 2 - 4 } & & 1. pisang goreng & 4 \\
& & 2. pisang bakar & 3 \\
3. pisang cokelat & 2 \\
Beranan & pisang & 4. pisang crispy & 5 \\
& & 5. pisang kaget & 5 \\
& & 7. pisang molen & 3 \\
& & 8. pisang tanduk & 0 \\
& & 9. pisang geprek & 3 \\
& kebab & kebab pisang & 5 \\
bongko & bongko pisang & 3
\end{tabular}




\begin{tabular}{ccll} 
& roti & roti pisang & 6 \\
& kolak & kolak pisang & 3 \\
& molen & molen pisang & 2 \\
& ledre & ledre pisang & 1 \\
& bolu & bolu pisang & 5 \\
& lasagna & lasagna pisang & 0 \\
\hline \multirow{4}{*}{ Makanan } & ledre & ledre pisang & 4 \\
& banana & 1. banana roll & 1 \\
& bolen & 2. banroll & 3 \\
& sale & bolen pisang & 1 \\
& tape & tape pisang & 4 \\
& keripik & rambak pisang & 3 \\
& puding & keripik pisang & 6 \\
& pie & pie pisang & 3 \\
& lumpia & lumpia pisang & 9 \\
& dadar & dadar gulung & 2 \\
& gulung & pisang & \\
& nuget & nuget pisang & 4 \\
\hline
\end{tabular}

\section{Kesimpulan}

Melalui studi etnosemantis, aspek budaya dalam sistem tata nama rakyat terkait penamaan makanan olahan buah pisang dapat diidentifikasi. Identifikasi tersebut diawali dengan deskripsi aspek formal bahasa yang membentuk nama tersebut diikuti dengan dasar penamaan makanan, modernisasi nama makanan tradisional, dan klasifikasi folk nama makanan. Dari aspek formal diketahui bahwa nama-nama makanan tersebut dibedakan menjadi tiga bentuk, yakni idiom, akronim, dan frasa endosentris atributif berinti nomina. Adapun dasar penamaan makanan yang digunakan dalam sistem tata nama tersebut dibedakan menjadi sebelas, yakni penamaan berdasarkan bahan pokok, jenis bahan pokok, bentuk, cara pengolahan, bahan tambahan, sifat, merek, ukuran, rasa, nama pembuat, dan nama tempat. Nama-nama makanan tersebut ada yang mengalami modernisasi menjadi beberapa varian dan ada pula yang tidak. Makanan tradisional pisang goreng berkembang menjadi 24 varian, pisang bakar menjadi tiga varian, bongko pisang menjadi tiga varian, kolak pisang menjadi tiga varian, sale pisang menjadi empat varian, ledre pisang menjadi lima varian, rambak pisang menjadi tiga varian, dan keripik pisang menjadi enam varian. Selain itu, makanan olahan pisang juga dijumpai dalam bentuk modifikasi baru. Dengan menggunakan spesifikasi modifikasi dengan standar makanan lain, makanan olahan pisang tersebut berkembang menjadi makanan modern. Nama-nama makanan tersebut, antara lain, kebab pisang, bongko pisang, roti pisang, molen pisang, bolu pisang, puding pisang, pie pisang, lumpia pisang, dadar gulung pisang, dan nuget pisang. Adapun makanan tradisional nagasari, pisang rebus, dan tape pisang tidak mengalami modernisasi. Hal ini menunjukkan bahwa nama-nama makanan tersebut memiliki fungsi yang tidak begitu penting dalam kehidupan masyarakat, khususnya di bidang ekonomi. Terkait klasifikasi folk makanan, nama makanan olahan buah pisang dikelompokkan menjadi lima kategori, yaitu unique beginner (jenis makanan), food form (bentuk makanan), generik, spesifik, dan varietal.

\section{Daftar Pustaka}

Amiruddin, Moh, Moh Rozek, dan Sulistiyanto Sulistiyanto. 2019. “'Kepo Mbah Kupis' Kripik Olahan dari Limbah Kulit Pisang Camilan Beraneka Rasa." Jurnal Abdimas Berdaya: Jurnal Pembelajaran, Pemberdayaan dan Pengabdian Masyarakat 2(02):12-18. doi: 10.30736/jab.v2i02.2.

Ba'dulu, Abdul Muis, dan Herman. 2005. Morfosintaksis. Jakarta: Rineka Cipta.

Baehaqie, Imam. 2017. Etnolinguistik: Telaah Teoritis dan Praktis. Surakarta: Yuma Pustaka. 
Busri, Hasan, dan Moh. Badrih. 2018. Linguistik Indonesia: Pengantar Memahami Hakikat Bahasa. Malang: Madani Media.

Chaer, Abdul. 2014. Linguistik Umum. Jakarta: Rineka Cipta.

Chaer, Abdul. 2015. Morfologi Bahasa Indonesia (Pendekatan Proses). Jakarta: Rineka Cipta.

Dörnyei, Zoltán. 2007. Research Methods in Applied Linguistics: Quantitative, Qualitative, and Mixed Methodologies. New York: Oxford University Press.

Eglin, Peter. 1980. Talk And Taxonomy: A Methodological Comparison of Ethnosemantics and Ethnomethodology with Reference to Terms for Canadian Doctors. Amsterdam: Johns Benjamins Publishing Company. https://doi.org/10.1075/pb.i.8

Fransiska, Silvia, Reniwati Reniwati, dan Lindawati Lindawati. 2019. "Penamaan Makanan Berbahan Ubi di Minangkabau." Jurnal Elektronik Wacana Etnik 8(1):23-31. doi: 10.25077/we.v8.i1.133.

Gurning, Riris Nadia Syafrilia, Sakral Hasby Puarada, dan Misril Fuadi. 2021. "Pemanfaatan Limbah Pisang Menjadi Selai Pisang Sebagai Peningkatan Nilai Guna Pisang." E-Dimas: Jurnal Pengabdian kepada Masyarakat 12(1):10611. https://doi.org/10.26877/edimas.v12i1.6395

Hadiyaniyah, Yani Nurfitri. 2016. “Leksikon Makanan Tradisional Sunda di Kabupaten Kuningan (Kajian Etnolinguistik)." Lokabasa 7(1):94-102. https:// doi.org/10.17509/jlb.v7i1.342 5
Huai, Khasbagan Hu-Yin, dan Sheng-Ji Pei. 2000. "Wild plants in the diet of Arhorchin Mongol herdsmen in inner Mongolia." Economic botany 54(4):528-36. https:// doi.org/10.1007/BF02866550

Kalle, Raivo, dan Renata Sõukand. 2021. “The name to remember: Flexibility and contextuality of preliterate folk plant categorization from the 1830s, in Pernau, Livonia, historical region on the eastern coast of the Baltic Sea." Journal of Ethnopharmacology 264:113254. https://doi.org/10.1016/j.jep.2020.113 254

Katamba, Francis. 1993. Morphology. New York: St. Martin's Press. https: / / doi.org/10.1007/978-1-34922851-5

Kesuma, Tri Mastoyo Jati. 2007. Pengantar (Metode) Penelitian Bahasa. Yogyakarta: Carasvatibooks.

Kridalaksana, Harimurti. 2009. Kamus Linguistik. Edisi Ke-4. Jakarta: Gramedia.

Loko, Laura Estelle Yêyinou, Joelle Toffa, Arlette Adjatin, Ahouélété Joel Akpo, Azize Orobiyi, dan Alexandre Dansi. 2018. "Folk taxonomy and traditional uses of common bean (Phaseolus vulgaris L.) landraces by the sociolinguistic groups in the central region of the Republic of Benin." Journal of ethnobiology and ethnomedicine 14(1):115. https://doi.org/10.1186/s13002018-0251-6

Mahsun, MS. 2014. Metode Penelitian Bahasa: Tahapan, Strategi, dan Tekniknya. Jakarta: Raja Grafindo Persada. 
Moeliono, Anton M., Hans Lapoliwa, Hasan Alwi, Sry Satrya Tjatur Wisnu Sasangka, dan Sugiyono. 2017. Tata Bahasa Baku Bahasa Indonesia. Edisi Ke-6. Jakarta: Badan Pengembangan dan Pembinaan Bahasa.

Muhammad. 2011. Paradigma Kualitatif Penelitian Bahasa. Yogyakarta: Liebe Book Press.

Mulyadi, Jendri. 2019. “Penamaan Tempat Usaha dan Menu Kuliner Spesifik Mi Pada Fitur GOO-FOOD dalam Aplikasi GO-JEK Area Padang: Kajian Semantik." Journal of RESIDU 3(18):50-63.

Munjidah, Afifatul. 2019. "Nama-Nama Jajanan Khas Arab." Deskripsi Bahasa 2(2):182-89.

https:/ / doi.org/10.22146/db.v2i2.359

Muslich, Masnur. 2014. Tata Bentuk Bahasa Indonesia: Kajian ke Arah Tatabahasa Deskriptif. Jakarta: PT. Bumi Aksara.

Nuari, Pramita Fara. 2020. “Penamaan Menu Makanan di Bali." BELAJAR BAHASA: Jurnal Ilmiah Program Studi Pendidikan Bahasa dan Sastra Indonesia 5(1):73-90. https:// doi.org/10.32528/bb.v5i1.300 8

Nugraha, Danang Satria. 2019. “The lexicons of animal classification in javanese: a cognitive semantics approach." International Journal of Humanity Studies (IJHS) 2(2):186-95. doi: 10.24071/ijhs.v2i2.1799.

Phaka, Fortunate M., Edward C. Netherlands, Donnavan J. D. Kruger, dan Louis H. Du Preez. 2019. "Folk taxonomy and indigenous names for frogs in Zululand, South Africa." Journal of ethnobiology and ethnomedicine 15(1):18. https://doi.org/10.1186/s13002019-0294-3

Putri, T. K., D. Veronika, Ade Ismail, Agung Karuniawan, Yudithia Maxiselly, Aep Wawan Irwan, dan Wawan Sutari. 2015. "Pemanfaatan jenis-jenis pisang (banana dan plantain) lokal Jawa Barat berbasis produk sale dan tepung." Kultivasi 14(2). https:// doi.org/10.24198/kultivasi.v1 $4 \mathrm{i} 2.12074$

Qurniati, Rommy, Duryat Duryat, Hendra Prasetya, dan Ferli Hartati. 2020. "Olahan Pisang sebagai Penunjang Ekonomi Masyarakat di Sekitar Gunung Rajabasa Lampung." J-ABDIPAMAS (Jurnal Pengabdian Kepada Masyarakat) 4(2):117-24.

https:/ / doi.org/10.30734/jabdipamas.v4i2.1217

Ramlan, M. 2005. Ilmu Bahasa Indonesia: Sintaksis. Yogyakarta: CV. Karyono.

Sadapotto, Andi, dan Hasan Hasan. 2020. “Olahan Pisang Sebagai Upaya Meningkatkan Nilai Jual Pisang dan Pendapatan Masyarakat." Maspul Journal of Community Empowerment 1(1):88-100.

Sudaryanto. 2015. Metode dan Aneka Teknik Analisis Bahasa: Pengantar Penelitian Wahana Kebudayaan secara Linguistis. Yogyakarta: Sanata Dharma University Press.

Suhandano, Suhandano. 2000. “Klasifikasi Folk Biologi dalam Bahasa Jawa sebuah Pengamatan Awal." Humaniora 12(2):225-30. doi: 10.22146/jh.694.

Suhandano, Suhandano. 2007. "Kategori Tumbuh-tumbuhan Wit dan Suket 
dalam Bahasa Jawa." Humaniora 19(1):89-97. doi: 10.22146/jh.895.

Sunandar, Asep, Raden Bambang Sumarsono, Djum Djum Noor Benty, dan Nunung Nurjanah. 2017. "Aneka Olahan Pisang Sebagai Upaya Meningkatkan Nilai Jual Pisang Dan Pendapatan Masyarakat." Abdimas Pedagogi: Jurnal Ilmiah Pengabdian kepada Masyarakat 1(1):8-15. doi: 10.17977/um050v1i1p\%25p.

Tokuoka, Yoshinori, Fukuhiro Yamasaki, Kenichiro Kimura, Kiyokazu Hashigoe, dan Mitsunori Oka. 2019. “Tracing chronological shifts in farmland demarcation trees in southwestern Japan: implications from species distribution patterns, folk nomenclature, and multiple usage." Journal of ethnobiology and ethnomedicine 15(1):1-10. https://doi.org/10.1186/s13002-0190301-8

Turpin, Myfany, dan Aung Si. 2017. “Edible insect larvae in Kaytetye: Their nomenclature and significance." Journal of Ethnobiology 37(1):120-40. https:/ / doi.org/10.2993/0278-077137.1.120
Ulicsni, Viktor, Ingvar Svanberg, dan Zsolt Molnár. 2016. "Folk knowledge of invertebrates in Central Europe-folk taxonomy, nomenclature, medicinal and other uses, folklore, and nature conservation." Journal of ethnobiology and ethnomedicine 12(1):1-40. https:// doi.org/10.1186/s13002-0160118-7

Wang, Jing, Barnabas C. Seyler, Tamara Ticktin, Yonggang Zeng, dan Kede Ayu. 2020. "An ethnobotanical survey of wild edible plants used by the Yi people of Liangshan Prefecture, Sichuan Province, China." Journal of ethnobiology and ethnomedicine 16(1):1-27. https:// doi.org/10.1186/s13002-0190349-5

Zaim, M. 2015. "Pergeseran Sistem Pembentukan Kata Bahasa Indonesia: Kajian Akronim, Blending, dan Kliping." Linguistik Indonesia 33(2):173-92. doi: 10.26499/li.v33i2.36. 